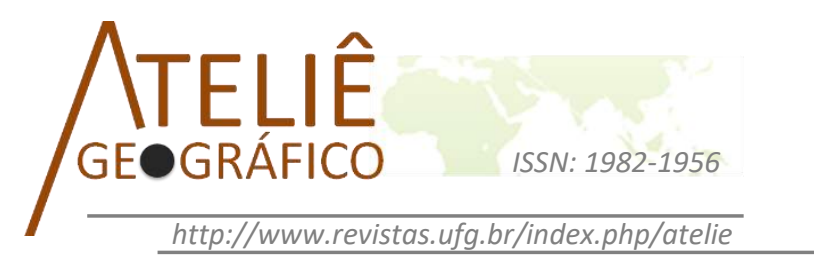

\title{
Qualidade ambiental da área urbana de Paranaguá, Pr.
}

Environmental quality of Paranagua urban area, Pr.

Calidad ambiental de la zona urbana de Paranaguá, Pr.

\author{
Emerson Luis Tonetti \\ Instituto Federal do Paraná- campus Paranaguá \\ emerson.tonetti@ifpr.edu.br
}

\author{
João Carlos Nucci \\ Universidade Federal do Paraná \\ jcnucci@gmail.com \\ Felipe Vanhoni Jorge \\ Universidade Federal do Paraná \\ felipevanhoni@hotmail.com
}

\begin{abstract}
Resumo
O presente estudo teve por objetivo identificar e representar cartograficamente a qualidade ambiental em um segmento urbano do Município de Paranaguá, no litoral do Estado do Paraná. A carta de qualidade ambiental urbana foi elaborada com base no levantamento e representação cartográfica de parâmetros negativos de determinados critérios em escalas que valorizem o cotidiano do cidadão, que foram: cobertura vegetal reduzida ou ausente, arborização viária reduzida ou ausente, usos do solo e vias potencialmente poluidores, ausência de espaços de uso público e livres de edificação e suas áreas de influência, verticalidade das edificações acima de quatro pavimentos, áreas frequentemente inundáveis e/ou alagáveis, calçadas e ciclovias com dificuldades para o deslocamento de pedestres ou ciclista. Evidenciou-se uma grande área com baixa qualidade ambiental que acompanha o traçado das principais vias de acesso rodoviário e ferroviário ao Porto Dom Pedro II. Da mesma forma, a intensa presença do uso comercial elou a intensidade do tráfego de veículos leves em muitas localidades favorecem as perdas da qualidade ambiental da área estudada.
\end{abstract}

Palavras chave: Paranaguá, qualidade ambiental, planejamento da paisagem

\section{Abstract}

This study aimed at identifying and representing the environmental quality cartographically in an urban segment of the city of Paranagua, on the coast of Parana. The map 
of urban environmental quality has been prepared based on the survey and cartographic representation of negative parameters of certain criteria on scales that value the citizen's routine that were: reduced or absent vegetation cover, reduced or absent vegetation on streets, potentially polluting use of land and streets, lack of open spaces, free of construction and their areas of influence, the height buildings above four stories, frequently flooded areas, sidewalks and bicycle lanes with that impose danger for the pedestrian or cyclist. The map in question enabled the scrutiny of a large area with low environmental quality which follows the path of the main roads and railways that lead to the Dom Pedro II Port. Similarly, the intense presence of commercial use and/or the intensity of light vehicle traffic in many localities encourages loss of environmental quality of the area studied.

Keywords: Paranagua, environmental quality, landscape planning

\begin{abstract}
Resumen
Este estudio tuvo como objetivo identificar y representar la cartografía de la calidad ambiental en un segmento urbano de la ciudad de Paranaguá, en Paraná litoral del estado. La carta de la calidad del medio ambiente urbano há sido preparada con base en el levantamiento y representación cartográfica de los parámetros negativos de ciertos criterios en escalas que valoren la vida cotidiana de los ciudadanos, a saber: cubierta vegetal reducida o ausente, arborización viaria reducida o ausente, usos del terreno y vías potencialmente contaminantes, la falta de sitios para el uso público y libres de edificaciones en su zona de influencia, verticalidad de los edificios por encima de cuatro pisos, zonas frecuentemente inundadas y/o alagadas, aceras y carril bici con dificultades para el movimiento peatonal o ciclista. Se constató una amplia zona con baja calidad ambiental que acompaña el diseño de las principales vías de acceso por carretera y ferrocarril hasta el Puerto Don Pedro II. Del mismo modo, la intensa presencia para el uso comercial ylo la intensidad del tráfico de vehículos ligeros en muchas localidades favorecen las pérdidas de calidad ambiental de la zona estudiada.
\end{abstract}

Palabras clave: Paranaguá, calidad ambiental, planificación del paisaje

\title{
Introdução
}

Vive-se em um momento de crise das relações da sociedade com a natureza, podendo-se dar especial destaque para os centros urbanos, que muitas vezes, pela intensidade e distribuição dos usos do solo, apresentam alterações físicas, químicas e biológicas que se tornam inadequadas para as necessidades do ser humano. $O$ entendimento do processo da perda da Qualidade Ambiental é fundamental para subsidiar os gestores urbanos na elaboração de normas que regulem e limitem a exploração e o uso dos recursos.

O Município de Paranaguá, localizado no litoral do Estado do Paraná, está inserido na maior área contínua da Mata Atlântica do Brasil e, estando rodeado por Unidades de Conservação da Natureza, apresenta potencialidade para sustentar uma alta qualidade ambiental. No entanto, o recente, acelerado e desordenado crescimento urbano horizontal, associado com as atividades e vias do Porto D. Pedro II, ou porto de Paranaguá, indicam baixa qualidade do ambiente urbano. 
Assim, infere-se que os usos presentes na área urbana de Paranaguá e as suas interações resultantes, além de outros tipos de usos e interações associados a infraestrutura urbana da área, estejam colaborando com a diminuição da qualidade ambiental urbana, por serem fontes importantes de poluição, tensões e/ou conflitos com o uso residencial.

O objetivo do estudo foi o de identificar e representar cartograficamente a qualidade ambiental em um segmento da área urbana do município de Paranaguá.

O Plano Diretor de Desenvolvimento Integrado de Paranaguá indica que o adensamento populacional por verticalização das edificações é a alternativa para atender a demanda por habitações. Edificações com até 12 pavimentos estão previstas nos Setores Especiais de Adensamento propostos pelo Plano Diretor (PARANAGUÁ, 2007). Esses setores estão atrelados principalmente a presença da infraestrutura urbana instalada nas principais vias de acesso rodoviário do município. A área urbana do município que concentra a maior parte dos setores especiais de adensamento também é a área urbana mais consolidada e, por esse motivo, foi escolhida para compor o recorte espacial da pesquisa.

Essa pesquisa faz parte de um contexto que visou a identificação de áreas não adensáveis (TONETTI, 2011), dentro da linha do Planejamento da Paisagem (KIEMSTEDT et al., 1998), uma teoria que incorpora a avaliação das potencialidades (limites e aptidões) da natureza e da paisagem para acolher os usos humanos (NUCCI, 2008, 2009 e 2010).

\section{Fundamentação Teórica}

$\mathrm{Na}$ literatura encontram-se diferentes definições para o termo qualidade ambiental (KAMP et al., 2003), sendo muitas vezes esse termo confundido com o conceito de qualidade de vida.

Com base nas definições e nos modelos teóricos apresentados por Kamp et al. (2003) e nos estudos realizados por Nucci (2008), Tonetti (2011, p. 37 e 38) considerou o conceito de qualidade ambiental como parte de um conceito mais abrangente, que é o conceito de qualidade de vida, e como a amplitude de condições favoráveis do ambiente, ou seja, dos aspectos físicos, químicos e biológicos do local de estudo que suprem as necessidades fisiológicas do ser humano.

A produção acadêmica sobre qualidade ambiental urbana no Brasil, fundamentada nos princípios do Planejamento da Paisagem (KIEMSTEDT et al., 1998), aumentou e difundiu-se nos últimos anos conforme demostram os trabalhos de Tonetti (2011, p. 4043) e Estêvez (2014, p. 49 e 50). Critérios e parâmetros, sugeridos por diferentes autores, tem sido propostos para serem utilizados na avaliação da qualidade ambiental urbana, como destacou Estêvez (2014, p. 55 - 59).

A preocupação com a qualidade ambiental urbana não se restringe à Ciência. A Lei Orgânica do Município de Paranaguá, por exemplo, em consonância com a 
Constituição Federal brasileira, dispõe que sua política urbana deverá promover programas destinados a melhorar as condições ambientais das áreas urbanas, para assegurar a todos os cidadãos o direito ao meio ambiente ecologicamente saudável e equilibrado, essencial à qualidade de vida (PARANAGUÁ, 1990, artigos 203 e 211).

Um dos princípios do Plano Diretor de Desenvolvimento Integrado de Paranaguá é a preservação, a recuperação e a valorização do ambiente e entre suas diretrizes e objetivos consta a elevação da qualidade do ambiente urbano (art. 16, i. IX) (PARANAGUÁ, 2007). Ainda, segundo o Plano Diretor, entende-se por meio ambiente "a interação dos fatores físicos, químicos e biológicos” (PARANAGUÁ, 2007, LC 68, art. 128, § 1).

Desta forma, pode-se deduzir que melhorar a qualidade do ambiente urbano, em Paranaguá, significa melhorar as condições físicas, químicas e biológicas das áreas urbanas do Município, visando um ambiente ecologicamente saudável e equilibrado.

Assim, parte-se do pressuposto de que a presença da infraestrutura urbana (água, esgoto, energia elétrica, asfalto nas ruas) não é garantia suficiente de que o meio físico seja adequado para as pessoas viverem.

Desta forma, os aspectos físicos, químicos e biológicos do ambiente devem ser avaliados, ou seja, deve-se avaliar a qualidade do ambiente considerando-se outros critérios e parâmetros para além da infraestrutura tradicionalmente considerada nessas questões.

A presença da vegetação, um critério geralmente negligenciado, constitui um importante indicador da qualidade do ambiente urbano por trazer inúmeros benefícios (MARCUS e DETWYLER, 1972; CAVALHEIRO, 1991; SUKOPP e WERNER, 1991; SPIRN, 1995; HOUGH, 1998; KIEMSTEDT et al.,1998; NUCCI, 2008).

O conceito de cobertura vegetal, proposto por Cavalheiro et al. (1999, p. 7), que resumidamente representam as "manchas de vegetação", de porte arbóreo, arbustivo ou herbáceo, visualizadas a olho nu em imagem de satélite ou fotografias aéreas, é de grande valia na avaliação da qualidade ambiental urbana, sendo de no mínimo 5\% para a cobertura vegetal urbana o parâmetro menos restritivo encontrado por Nucci (2008, p. 24) na literatura.

A arborização viária faz parte da cobertura vegetal de uma cidade e está em destaque na paisagem urbana porque se localiza entre as vias de tráfego de veículos, os pedestres e as edificações, contribuindo para segurança do pedestre, para o conforto térmico, para o estabelecimento da conectividade entre as manchas com vegetação do meio urbano e deste com o rural, entre outras funções. (TONETTI, 2011, p. 51). Contudo, dependendo do porte e da continuidade dessa vegetação e da escala utilizada para o levantamento da cobertura vegetal, as árvores das calçadas podem não aparecer nas imagens, necessitando de outras técnicas de levantamento, por isso a arborização viária foi considerada por Tonetti (2011) como outro critério da qualidade do ambiente urbano, além da cobertura vegetal. 
Os poluentes também estão relacionados com os tipos de usos do solo, a intensidade do uso, as vias de tráfego e o desenho urbano em suas diferentes escalas (SPIRN, 1995; HOUGH, 1998; NUCCI, 2008). Tonetti (2011, p. 56) utilizou a distribuição dos usos do solo e a intensidade de tráfego nas vias de Paranaguá para constituir a carta de usos potencialmente poluidores, ou seja, como critério de poluição potencial.

Outro aspecto importante na determinação da qualidade ambiental urbana é o estudo dos espaços livres (CAVALHEIRO et al., 1999, p. 7). A localização, a quantidade e a qualidade dos espaços livres são requisitos importantes na determinação da qualidade ambiental (NUCCI, 2008; TONETTI, 2011). A importância desse critério é potencializada ao se considerar que a maior parte do tempo livre dos cidadãos é investida em locais situados nas proximidades de suas habitações (SUKOPP e WERNER, 1991, p. 80). É comum encontrar crianças brincando nas calçadas e em meio aos carros nas áreas desprovidas de espaços de uso público, livres de edificação e com vegetação, os "EUPLEVs" (BUCCHERI FILHO, 2010), principalmente se forem pobres e sem possibilidades de frequentar outros espaços que requerem recursos financeiros.

Sobre o aumento da altura das edificações e seus benefícios, Lötsch (1984) considera que na verticalização acima de quatro pavimentos, o ganho de espaços livres é negligenciável e promove a sobrecarga da infraestrutura urbana instalada e, consequentemente, a perda da qualidade ambiental pela intensificação do uso e ocupação do solo com impactos negativos na água, no solo e no ar. Soma-se a isso, a redução da atividade física e o aumento dos problemas de saúde relacionados com as pessoas, principalmente as crianças pequenas, que moram nos andares superiores de grandes edifícios. Portanto, a verticalidade das edificações também pode ser considerada um critério de qualidade ambiental urbana.

As inundações e/ou alagamentos estão relacionados com o uso do solo, as formas de relevo, com o sistema de drenagem e com o regime de chuvas da região entre outras questões. Assim, o planejamento do uso do solo urbano deve considerar os processos envolvidos no ciclo da água para evitar problemas relacionados com as inundações e/ou alagamentos, com a diminuição e a contaminação da água superficial e subterrânea (SPIRN, 1995; HOUGH, 1998; BOLUND e HUNHAMMAR, 1999; MOTA, 1999; NUCCI, 2008). Neste sentido, deve-se considerar a espacialização das inundações e dos alagamentos como critério para determinação da qualidade ambiental urbana.

Pode-se considerar que é amplamente aceito que o uso da bicicleta e o modo de deslocamento a pé são atividades saudáveis. E se essa atividade física estiver associada aos compromissos diários pode-se melhorar a condição de saúde pelos benefícios que a atividade física proporciona e pela melhoria da qualidade do ambiente urbano por meio da redução do número de viagens de automóveis particulares e das suas consequências. (JACKSON, 2003; SILVA; LOPES, 2008; ZEKCER, 2008).

A existência da estrutura física para as pessoas se deslocarem por meios não motorizados de um ponto qualquer para outro dentro de uma área urbanizada pode ser 
considerada como uma potencialidade do ambiente para o ser humano, ou seja, o ambiente em que a pessoa vive proporciona a possibilidade de deslocamento e se ela o fizer poderá desfrutar das vantagens que esse atributo pode trazer para sua condição biológica e para seu ambiente. Por essa razão a potencialidade de deslocamento nas ciclovias e nas calçadas pode ser consideradas como critério do meio físico para avaliar a qualidade ambiental urbana (TONETTI, 2011, p. 70 e 140).

\section{Procedimentos Metodológicos}

O Município de Paranaguá está localizado no litoral do Estado do Paraná e apresenta uma área total de $826,65 \mathrm{~km}^{2}$, área urbana de $95,15 \mathrm{~km}^{2}$ e a área de estudo possui $11,64 \mathrm{~km}^{2}$ (FIGURA 1).

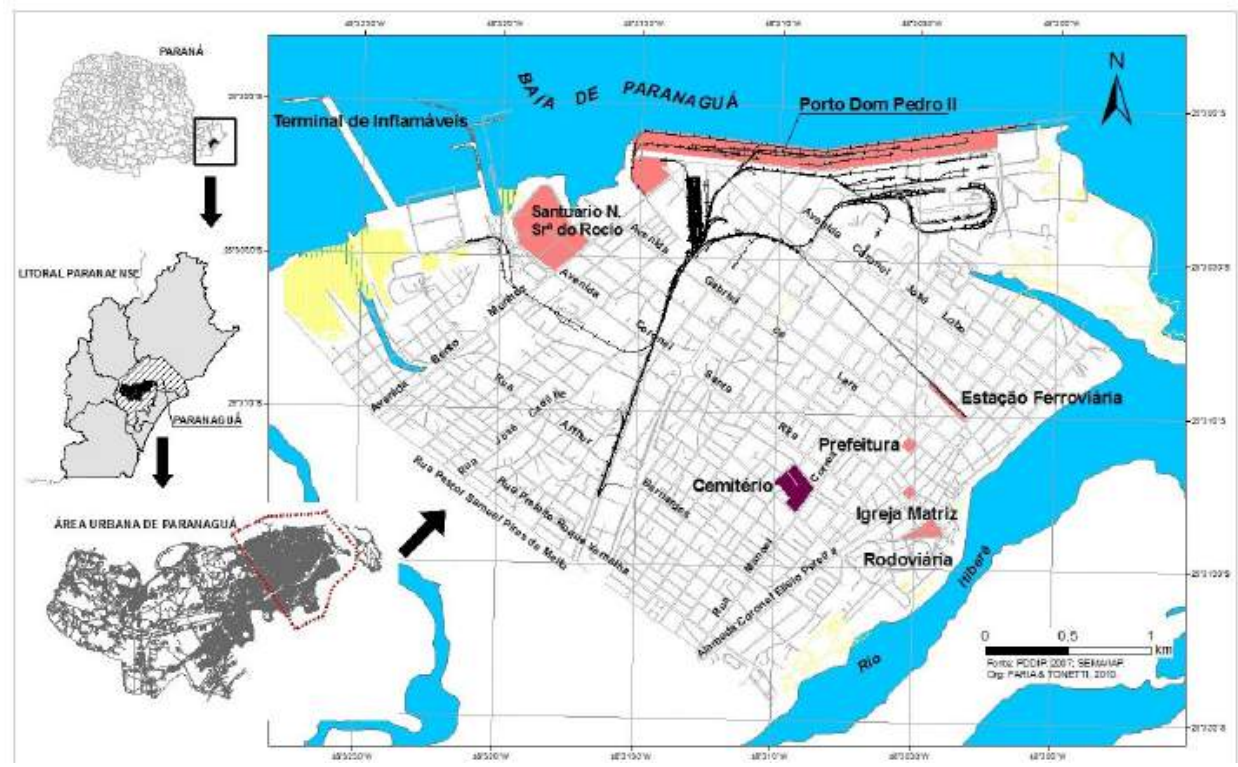

Figura 01: Localização da área de estudo com alguns pontos de referência. Fonte: Tonetti (2011, p. 130).

Esse recorte foi escolhido, pois concentra as áreas destinadas para o adensamento populacional por verticalização das edificações, conforme o Plano Diretor do município (PARANAGUÁ, 2007), dentro da zona urbana mais consolidada do município.

A determinação da qualidade ambiental foi estruturada no método desenvolvido por Nucci (1996 e 2008) que consiste na construção da carta de qualidade ambiental urbana, baseada no levantamento e representação cartográfica de parâmetros negativos de determinados critérios em escalas que valorizem o cotidiano do cidadão. (FIGURA 2) 


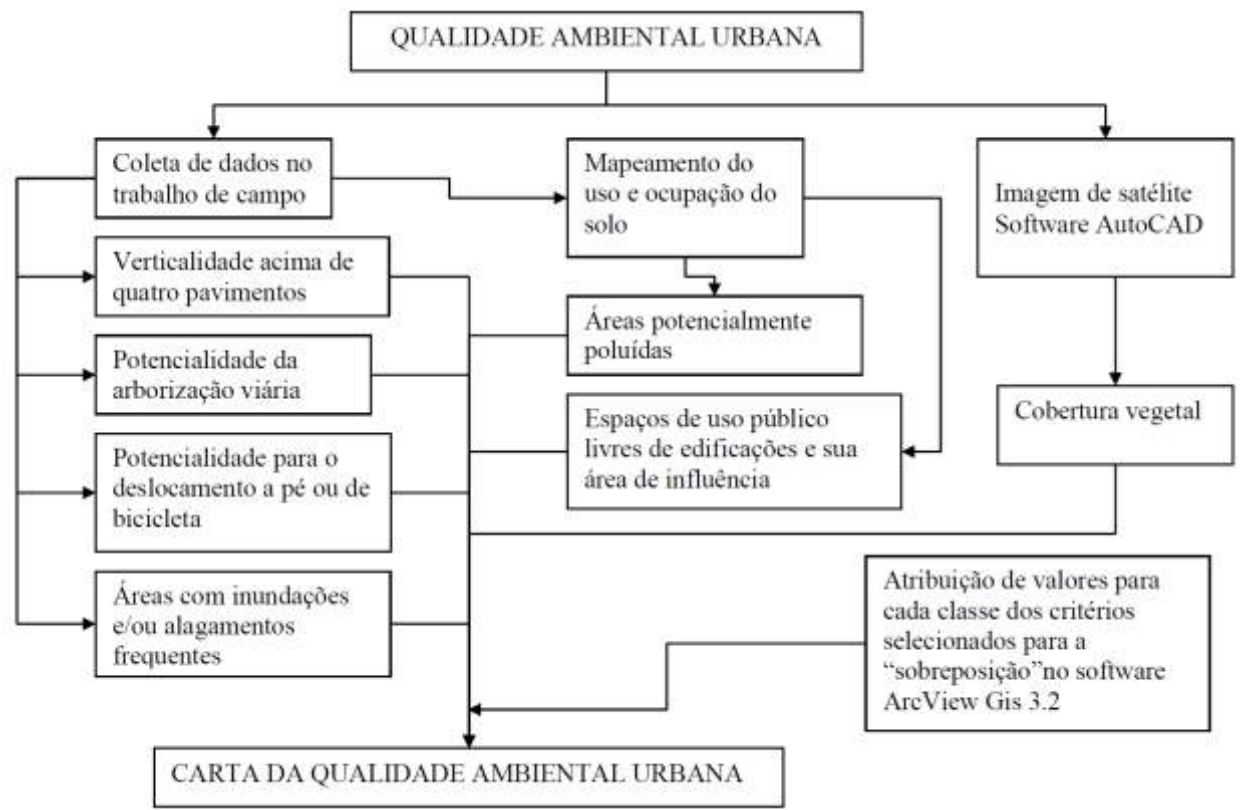

Figura 02: Fluxograma dos procedimentos para a elaboração da carta de qualidade ambiental ur-bana. Fonte: Tonetti (2011, p. 143).

A carta de cobertura vegetal foi elaborada com base em imagem de satélite Quickbird de 2006 georeferenciada sobreposta a carta base da área urbana do município, na escala 1:15.000. Com o auxílio do AutoCAD a cobertura vegetal foi identificada, mapeada e quantificada. Considerou-se como prejudicial para a qualidade ambiental as áreas com cobertura vegetal reduzida ou ausente. (TONETTI, 2011, p. 136; TONETTI; NUCCI; CRUZ-JUNIOR, 2011). Os valores numéricos que acompanham a legenda da carta de cobertura vegetal e das outras cartas foram utilizados na sobreposição das cartas temáticas para a constituição da Carta de Qualidade Ambiental. (FIGURA 3) 


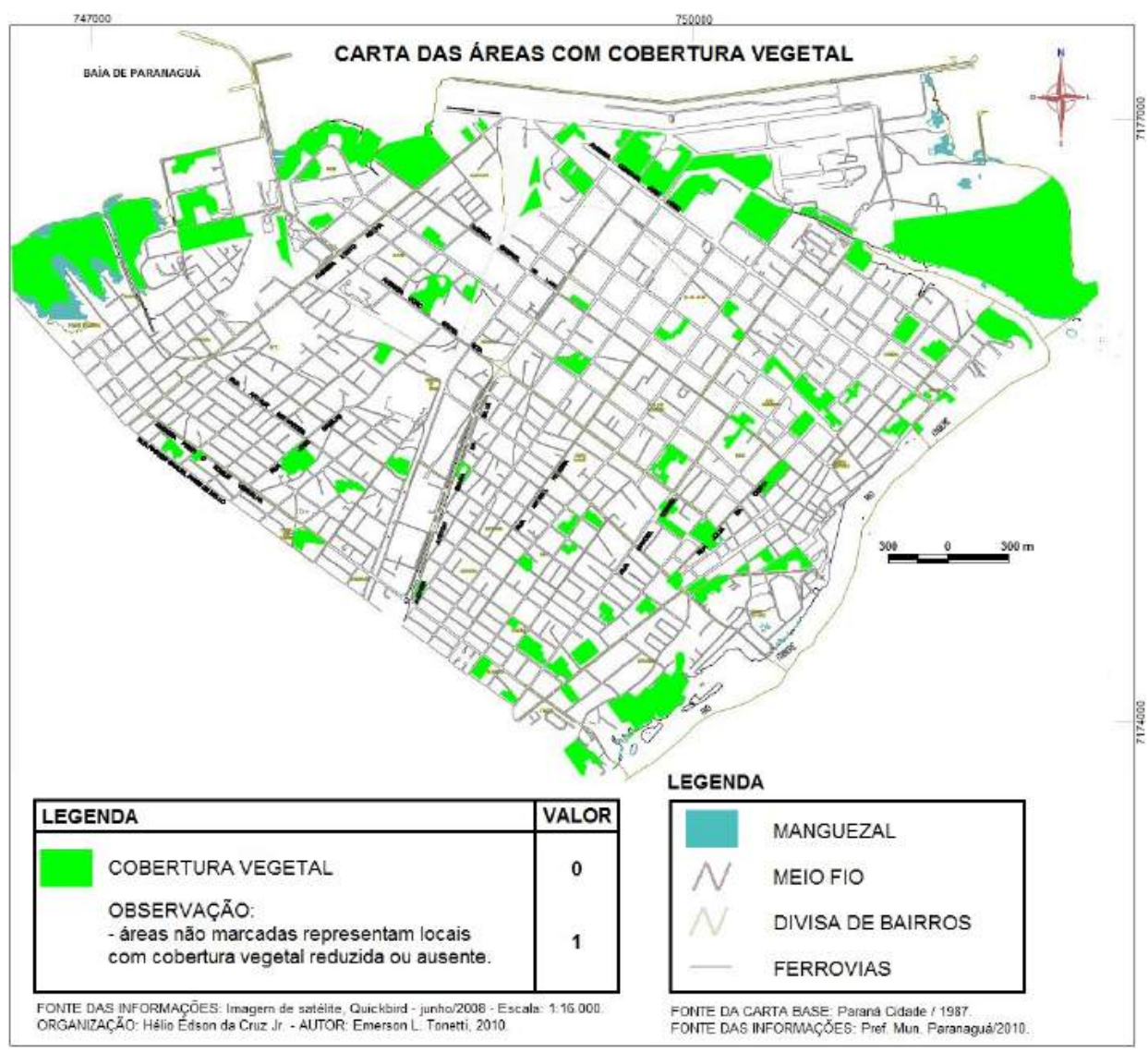

Figura 03: Distribuição da cobertura vegetal no local de estudo.

Fonte: Tonetti (2011, p. 147), Tonetti, Nucci e Cruz-Junior (2011).

Analisou-se, em campo, a qualidade e a distribuição espacial das árvores plantadas nas calçadas e canteiros centrais de avenidas. Foram consideradas como baixa qualidade ambiental as ruas que apresentaram menos do que $50 \%$ de arborização; média as ruas que apresentaram entre 50\% e 75\% de arborização e a rua com presença da arborização viária em mais de $75 \%$ do segmento foi caracterizada como de alta qualidade ambiental. Utilizando o programa AutoCAD, os dados coletados em campo foram lançados na carta base, na escala 1:15.000, para obtenção Da carta da qualidade da arborização viária. (TO-NETTI, 2011, p. 136 e 137, TONETTI; NUCCI, 2012). (FIGURA 4) 


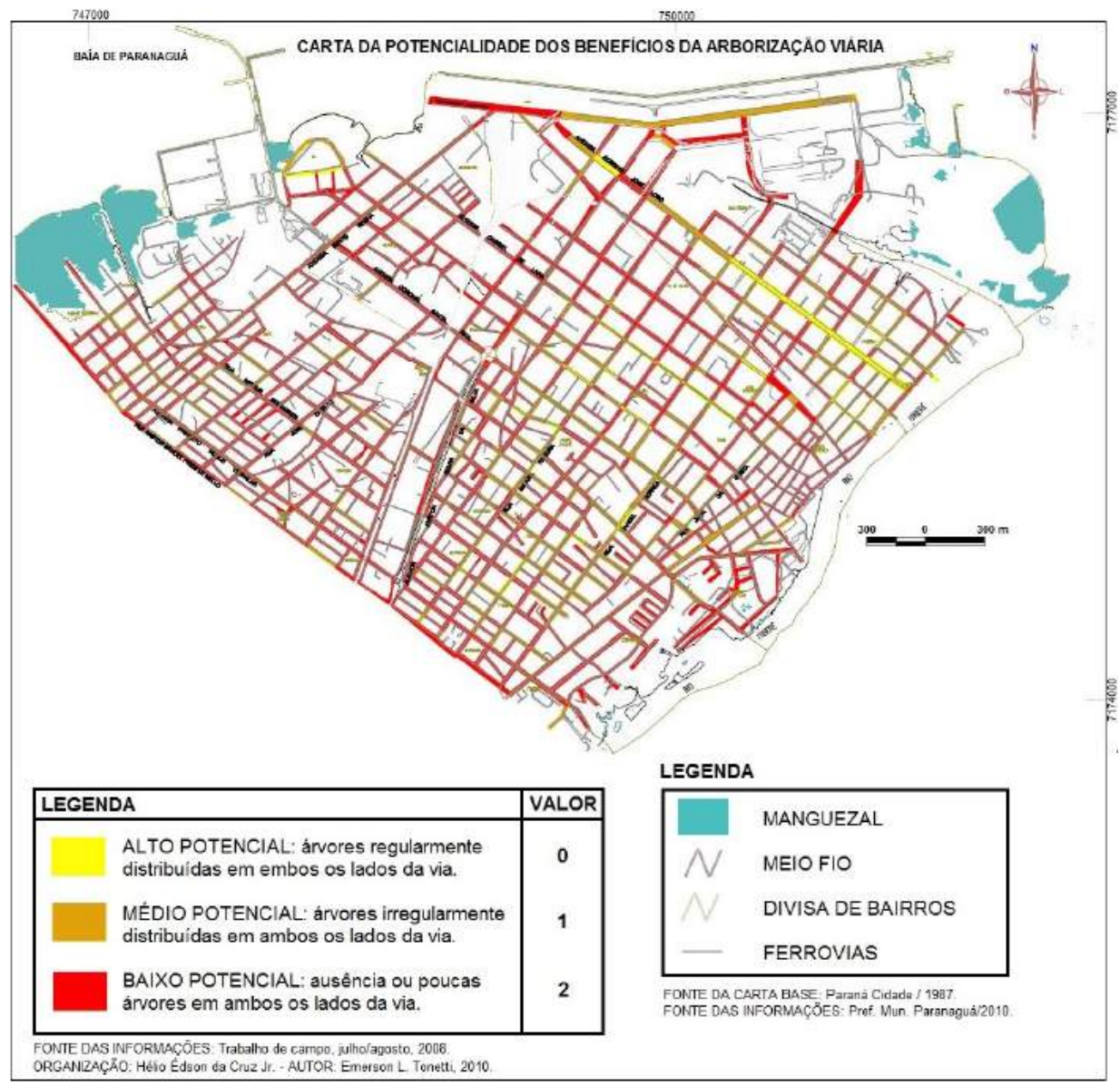

Figura 04: Distribuição da arborização viária no local de estudo.

Fonte: Tonetti (2011, p. 151), Tonetti e Nucci, 2012.

Foram identificados e espacializados os principais usos e vias com potencialidade para causar poluição. Os dados coletados em campo foram georeferenciados no AutoCAD e no ArcView Gis 3.2, gerando a carta de usos potencialmente causadores de poluição e vias de acesso e suas respectivas áreas de influência na escala 1:15.000. Foram considerados usos com maior potencial para causar poluição, os armazéns, as oficinas, postos de gasolina, entre outros. Usos como mercados de bairro, panificadoras, escolas e afins, foram considerados com menor potencial para causar poluição. Ferrovia, vias rodoviárias com tráfego intenso de veículos pesados e vias com tráfego intenso de veículos leves foram consideradas, relativamente entre si, com potencial alto, médio e baixo para causar poluição, respectivamente. (TONETTI, 2011, p. 137 e 138). (FIGURAS 5 e 6) 


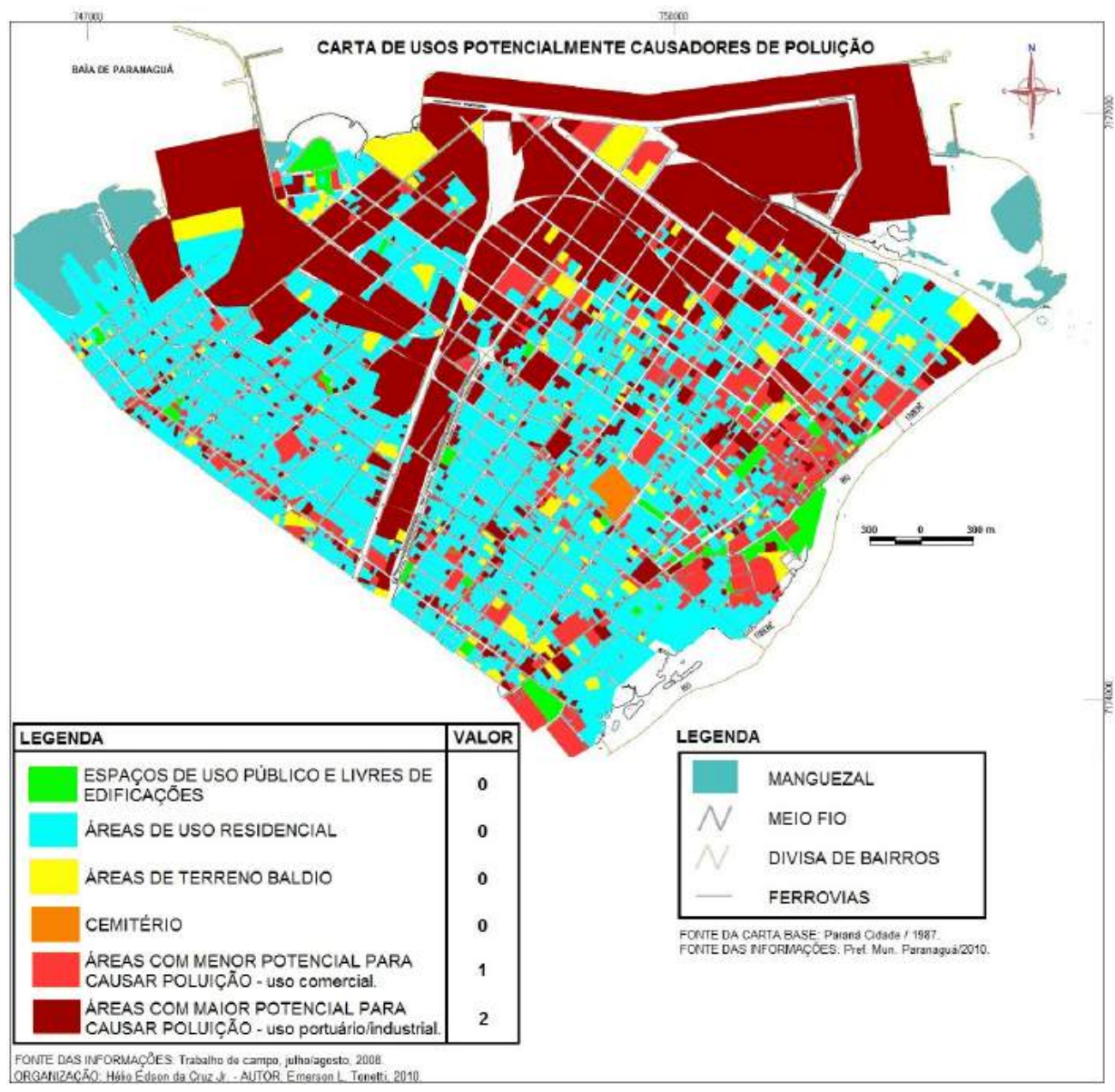

Figura 05: Distribuição dos usos potencialmente causadores de poluição do local de estudo. Fonte: Tonetti (2011, p. 155). 


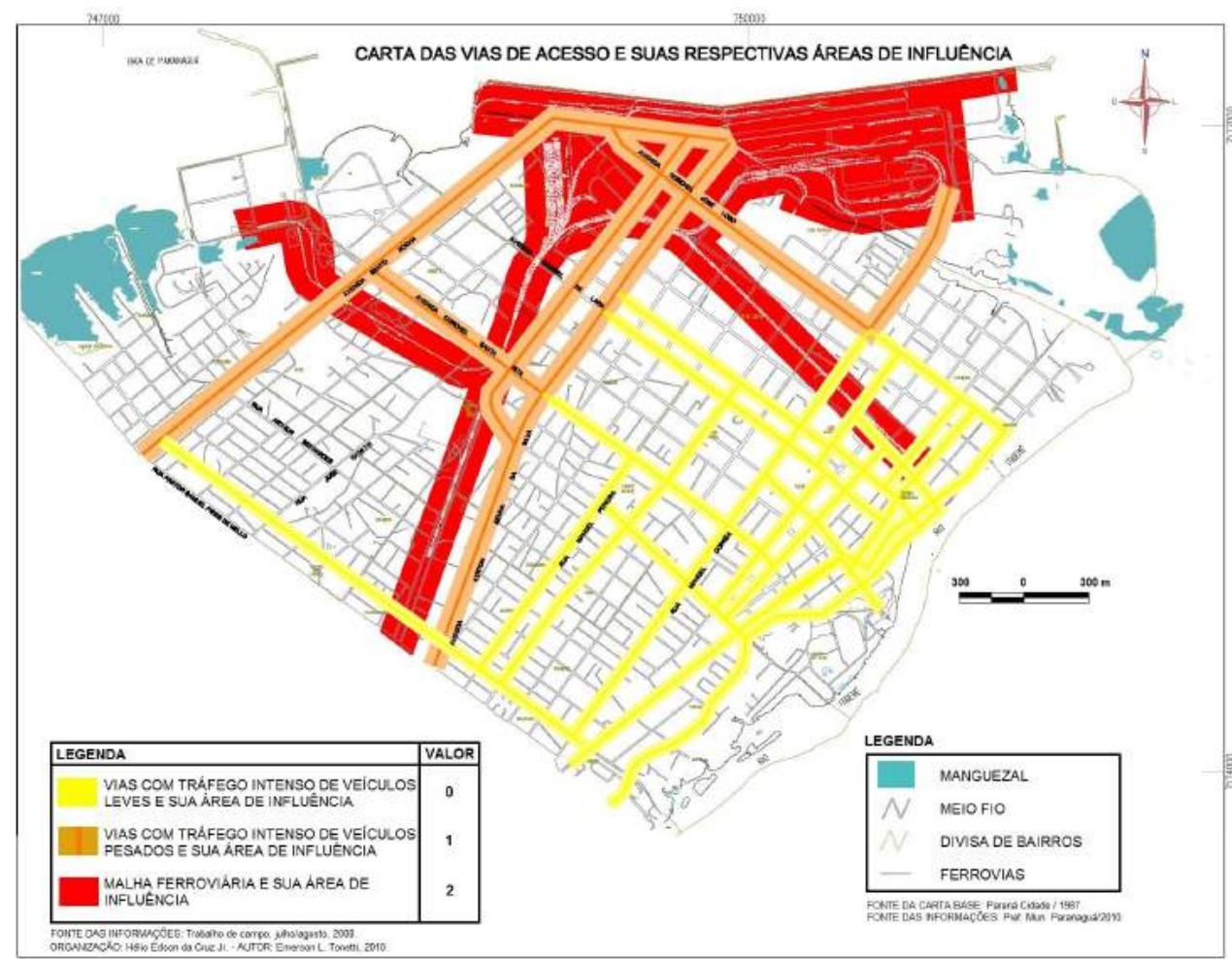

Figura 06: Distribuição das vias com tráfego intenso de veículos e suas respectivas áreas de influência pelo local de estudo.

Fonte: Tonetti (2011, p. 158).

Em trabalho de campo, os espaços de uso público e livres de edificações foram identificados e posteriormente mapeados em escala 1:15.000 por meio do software AutoCAD. Com base na literatura, o parâmetro adotado para demarcar a área da população assistida pelos espaços livres foi a distância de $300 \mathrm{~m}$, o que corresponde a no máximo 4 quadras que separariam a residência do espaço livre. Outro critério adotado foi a utilização das vias de tráfego intenso e desprovidas de semáforos, como barreiras para a utilização do espaço livre. (TONETTI, 2011, p. 138 e 139, TONETTI; NUCCI; VALASKI, 2012). (FIGURA 7) 


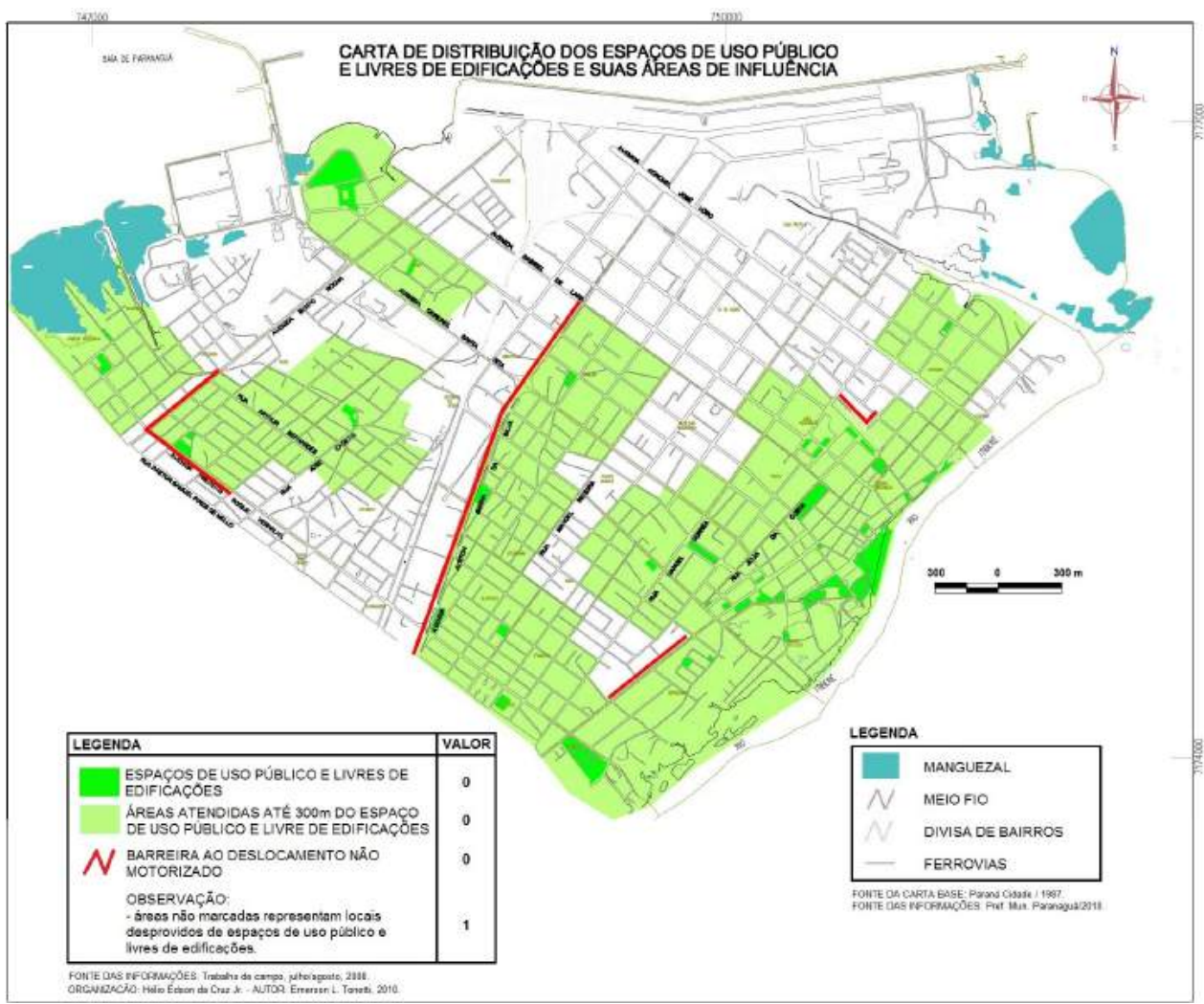

Figura 07: Distribuição dos espaços de uso público e livres de edificações e suas respectivas áreas de influência.

Fonte: Tonetti (2011, p. 161), Tonetti, Nucci e Valaski (2012).

Com base na literatura considerou-se que as edificações com mais de quatro pavimentos são prejudiciais para a qualidade ambiental urbana, ou seja, quanto mais se verticaliza, mais a qualidade do ambiente diminui e os impactos vão além da sobrecarga no sistema viário e da rede de esgotamento sanitário. Essas edificações foram identificadas em campo e posteriormente mapeados em escala 1:15.000 por meio do software AutoCAD, para gerar a carta das edificações com mais de quatro pavimentos. (TONETTI, 2011, p. 139). (FIGURA 8) 


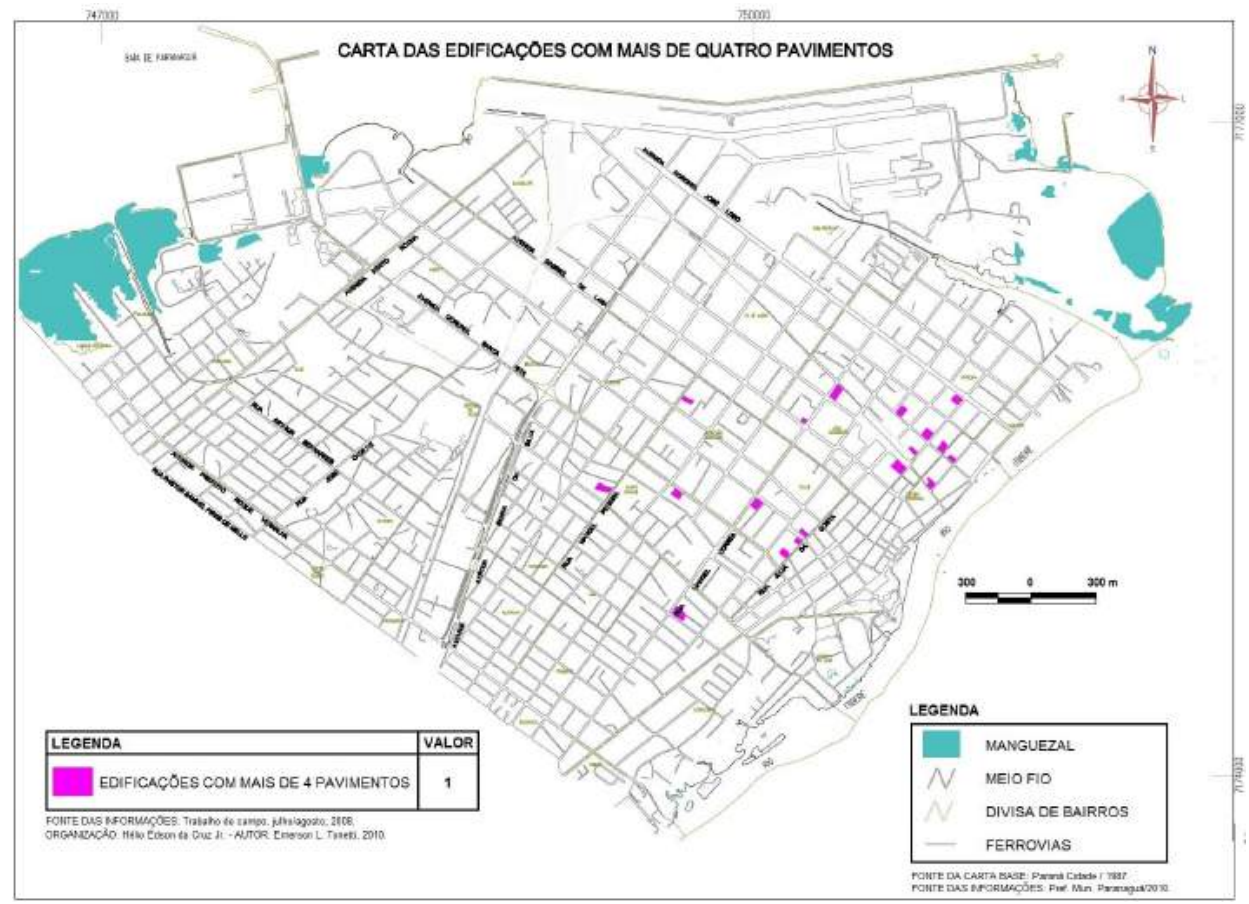

Figura 08: Distribuição das edificações com mais de quatro pavimentos pelo local de estudo. Fonte: Tonetti (2011, p. 166).

Consultas a empresa Águas de Paranaguá, a Prefeitura Municipal de Paranaguá, ao trabalho de Souza (2009) e as observações pessoais de mais de 15 anos de atividades profissionais na cidade de Paranaguá subsidiaram a elaboração da carta de distribuição dos locais com inundações frequentes. (TONETTI, 2011, p. 140, TONETTI, et al., 2013.). (FIGURA 9) 


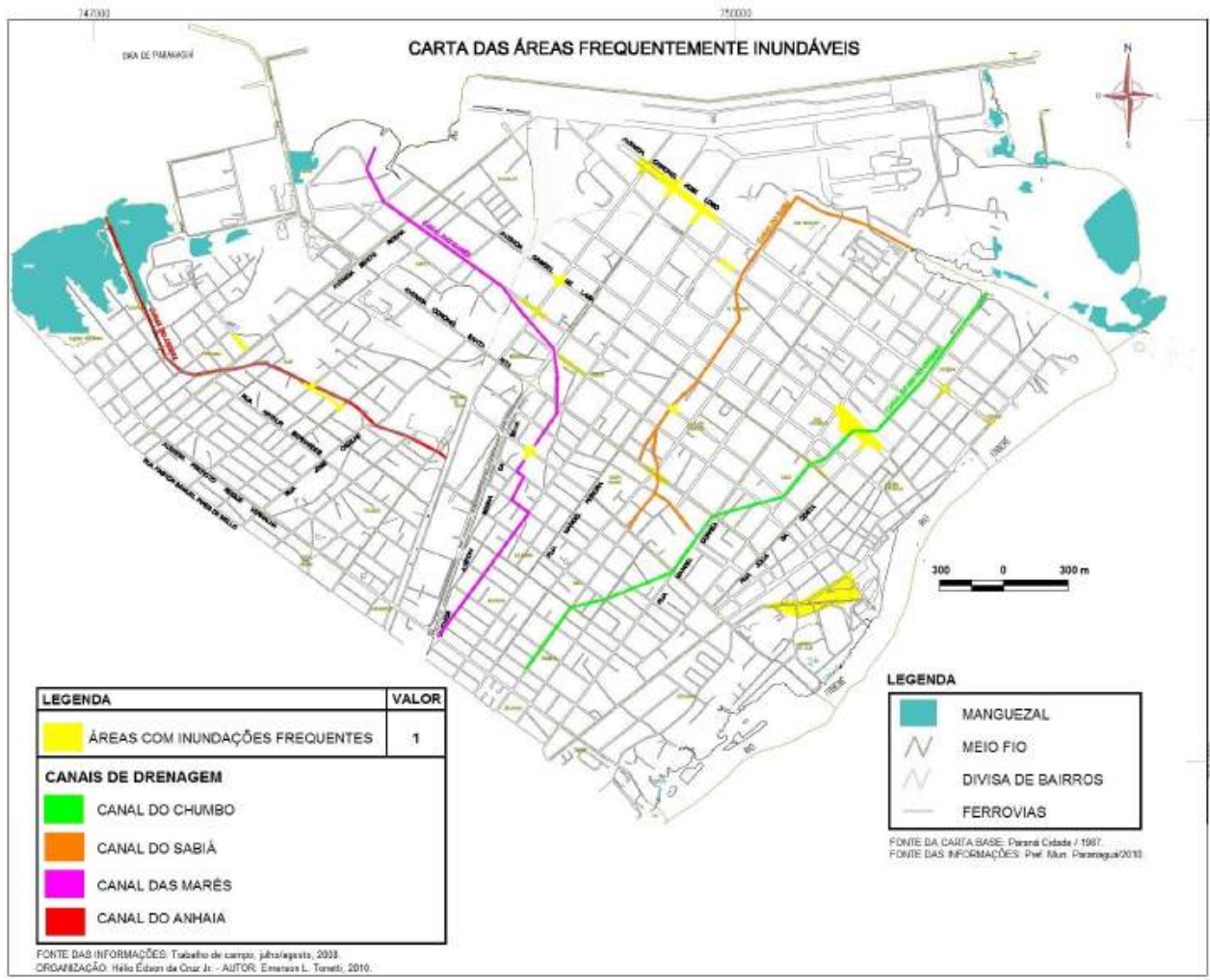

Figura 9: Distribuição das áreas com inundações frequentes e dos córregos canalizados no local de estudo.

Fonte: Tonetti (2011, p. 169), Tonetti et al., (2013).

As calçadas com a presença de muitas irregularidades (visualmente em campo acima de 50\%), em um ou nos dois lados da rua, obrigando o pedestre a sair da calçada e/ou a impossibilidade de se deslocar pela calçada em um ou em ambos os lados da rua, indicaram baixa qualidade ambiental. As calçadas com presença de irregularidades (visualmente até 50\%), em um ou em ambos os lados da rua, obrigando o pedestre a sair da calçada para se deslocar pela rua ou atravessá-la, foram consideradas como média qualidade ambiental. Aquelas com poucas (visualmente até $25 \%$ ) ou sem irregularidades, sendo possível o deslocamento sem sair da calçada nos dois lados da rua, foram consideradas como alta qualidade ambiental. (TONETTI, 2011, p. 140 e 141, FARIA, TONETTI; NU-CCI, 2013). (FIGURA 10) 


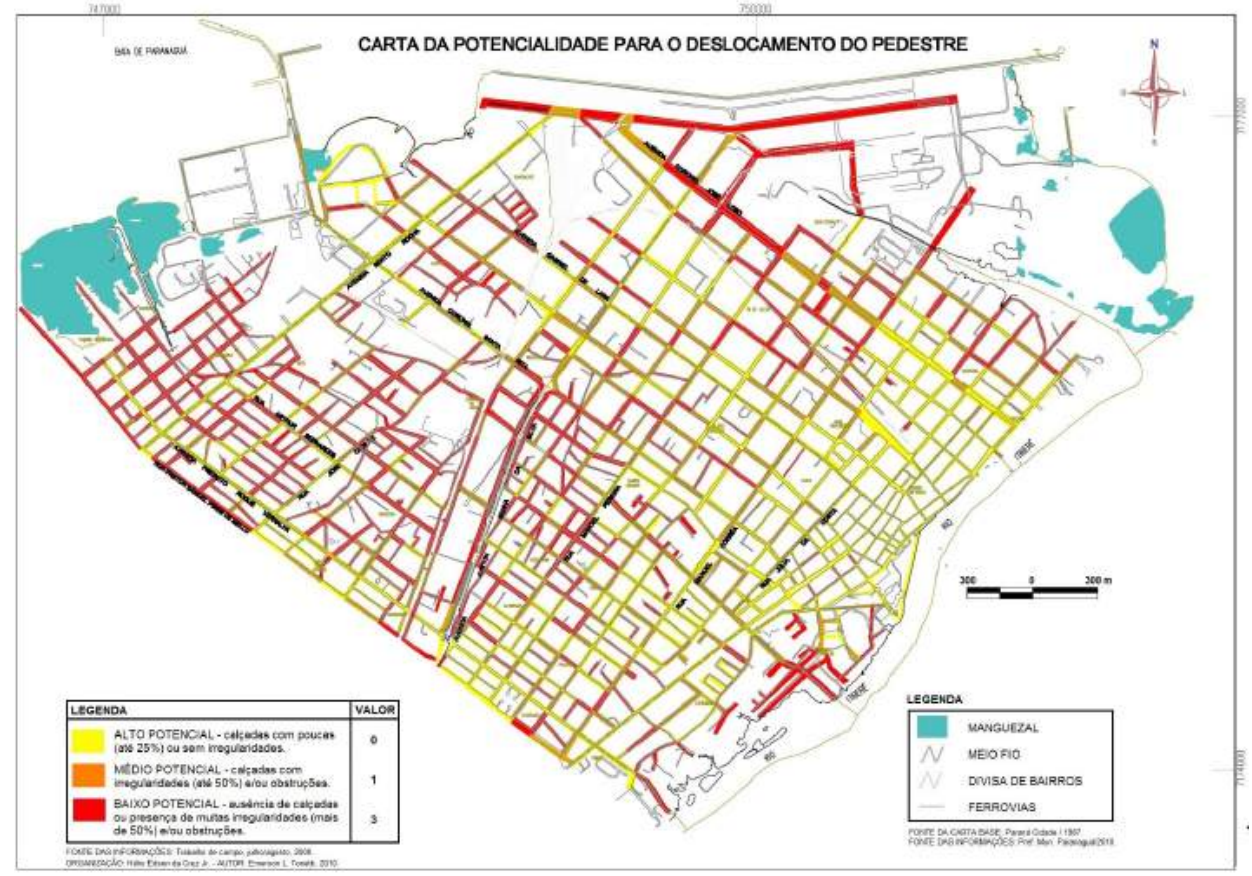

Figura 10: Distribuição da qualidade das calçadas pelo local de estudo.

Fonte: Tonetti (2011, p. 173), Faria, Tonetti e Nucci, 2013.

Os mesmos parâmetros descritos para classificação das calçadas, foram utilizados para a classificação das ciclovias do local de estudo. (TONETTI, 2011, p. 140 e 141, FA-RIA, TONETTI; NUCCI, 2013). (FIGURA 11) 


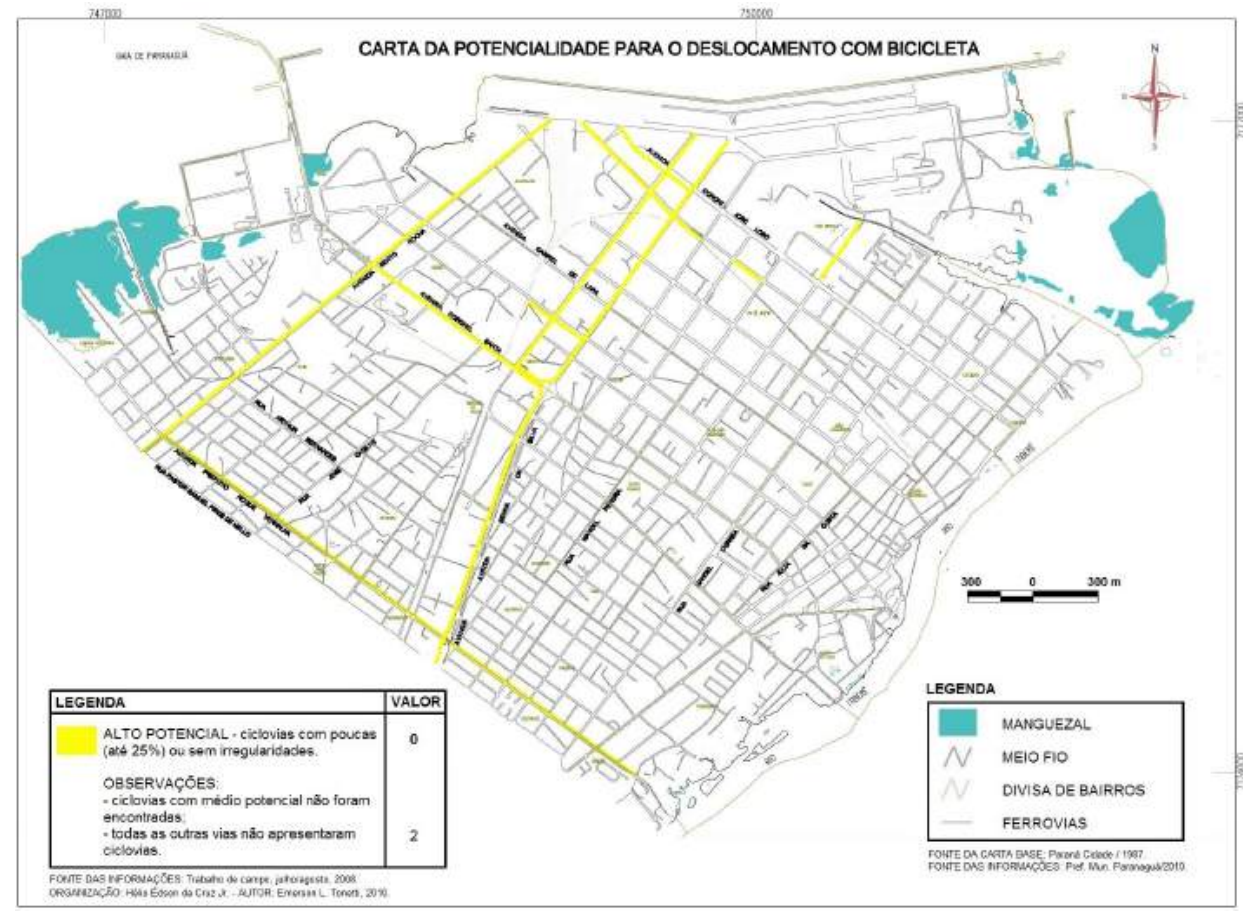

Figura 11: Distribuição e qualidade das ciclovias pelo local de estudo. Fonte: Tonetti (2011, p. 176), Faria, Tonetti e Nucci, 2013.

Para a elaboração da carta de qualidade ambiental, adotou-se a técnica de atribuir valores numéricos aos parâmetros espacializados de cada critério (QUADRO 1). Este é um procedimento necessário exigido pelo software ArcView Gis 3.2 para utilizá-lo como uma ferramenta na sobreposição dos critérios negativos, no processo de construção da referida carta da área de estudo. 
Quadro 01: Critérios, classes e parâmetros com seus respectivos valores para a classificação da qualidade ambiental urbana de Paranaguá.

\begin{tabular}{|c|c|c|}
\hline CRITÉRIOS & Classes e/ou alguns parâmetros & Valor \\
\hline Cobertura vegetal & $\begin{array}{l}\text { Presença de cobertura vegetal } \\
\text { Ausência de cobertura vegetal }\end{array}$ & $\begin{array}{l}0 \\
1\end{array}$ \\
\hline $\begin{array}{l}\text { Potencialidade dos benefícios } \\
\text { da arborização viária }\end{array}$ & $\begin{array}{l}\text { Alta } \\
\text { Média } \\
\text { Baixa }\end{array}$ & $\begin{array}{l}0 \\
1 \\
2\end{array}$ \\
\hline $\begin{array}{l}\text { Usos potencialmente } \\
\text { causadores de poluição }\end{array}$ & $\begin{array}{c}\text { Residencial } \\
\text { Terrenos baldios } \\
\text { Cemitérios } \\
\text { Espaços de uso público livres de edificações } \\
\text { Usos com menor potencial para causar poluição } \\
\text { Usos com maior potencial para causar poluição }\end{array}$ & $\begin{array}{l}0 \\
0 \\
0 \\
0 \\
1 \\
2\end{array}$ \\
\hline $\begin{array}{l}\text { Vias de acesso e suas respecti- } \\
\text { vas áreas de influência }\end{array}$ & $\begin{array}{c}\text { Vias com baixo tráfego de veículos } \\
\text { Vias com tráfego intenso de veículos leves } \\
\text { Vias com tráfego intenso de veículos pesados } \\
\text { Ferrovias }\end{array}$ & $\begin{array}{l}0 \\
1 \\
2 \\
3\end{array}$ \\
\hline $\begin{array}{l}\text { Espaços de uso público } \\
\text { livres de edificações e áreas de } \\
\text { influência }\end{array}$ & $\begin{array}{l}\text { Presença de espaços livres ou da sua área de influência } \\
\text { Ausência de espaços livres ou da sua área de influência }\end{array}$ & $\begin{array}{l}0 \\
1\end{array}$ \\
\hline Verticalidade das edificações & $\begin{array}{c}\text { Edificações com até } 4 \text { pavimentos } \\
\text { Edificações com mais de } 4 \text { pavimentos }\end{array}$ & $\begin{array}{l}0 \\
1\end{array}$ \\
\hline $\begin{array}{l}\text { Áreas frequentemente } \\
\text { inundáveis elou alagáveis }\end{array}$ & $\begin{array}{l}\text { Áreas sem inundações frequentes } \\
\text { Áreas frequentemente inundáveis }\end{array}$ & $\begin{array}{l}0 \\
1\end{array}$ \\
\hline $\begin{array}{l}\text { Potencialidade dos benefícios } \\
\text { do deslocamento a pé }\end{array}$ & $\begin{array}{l}\text { Alta } \\
\text { Média } \\
\text { Baixa }\end{array}$ & $\begin{array}{l}0 \\
1 \\
2\end{array}$ \\
\hline $\begin{array}{l}\text { Potencialidade dos } \\
\text { benefícios do deslocamento } \\
\text { com bicicleta }\end{array}$ & $\begin{array}{l}\text { Alta } \\
\text { Média } \\
\text { Baixa }\end{array}$ & $\begin{array}{l}0 \\
1 \\
2\end{array}$ \\
\hline
\end{tabular}

Fonte: Tonetti (2011, p. 141).

A sobreposição dos valores de cada uma das cartas temáticas indicou os locais onde a qualidade ambiental era menor. Assim, a carta de qualidade ambiental urbana 
classifica as áreas com base no valor obtido que é a resultante do número de critérios negativos presentes em cada local, ou seja, trata-se de uma carta de restrições.

\section{Resultados e Discussão}

A Carta de Qualidade Ambiental está sendo apresentada em escala 1:15.000, porém, destaca-se que o levantamento dos critérios de qualidade em campo e em imagens de satélite em escalas que considerem a vida do cidadão, resultou em uma cartografia com um detalhe imprescindível para o planejamento urbano.

As diferentes tonalidades, na Carta de Qualidade Ambiental, representam a gradação da qualidade, ou seja, os tons mais escuros indicam as áreas com a pior qualidade ambiental devido à maior sobreposição dos critérios negativos. As áreas em branco na mancha urbana, com valor zero, indica que nenhum dos critérios negativos adotados neste trabalho foi encontrado, o que não significa que possa haver qualquer outro problema que também diminua a qualidade ambiental. (FIGURA 12).

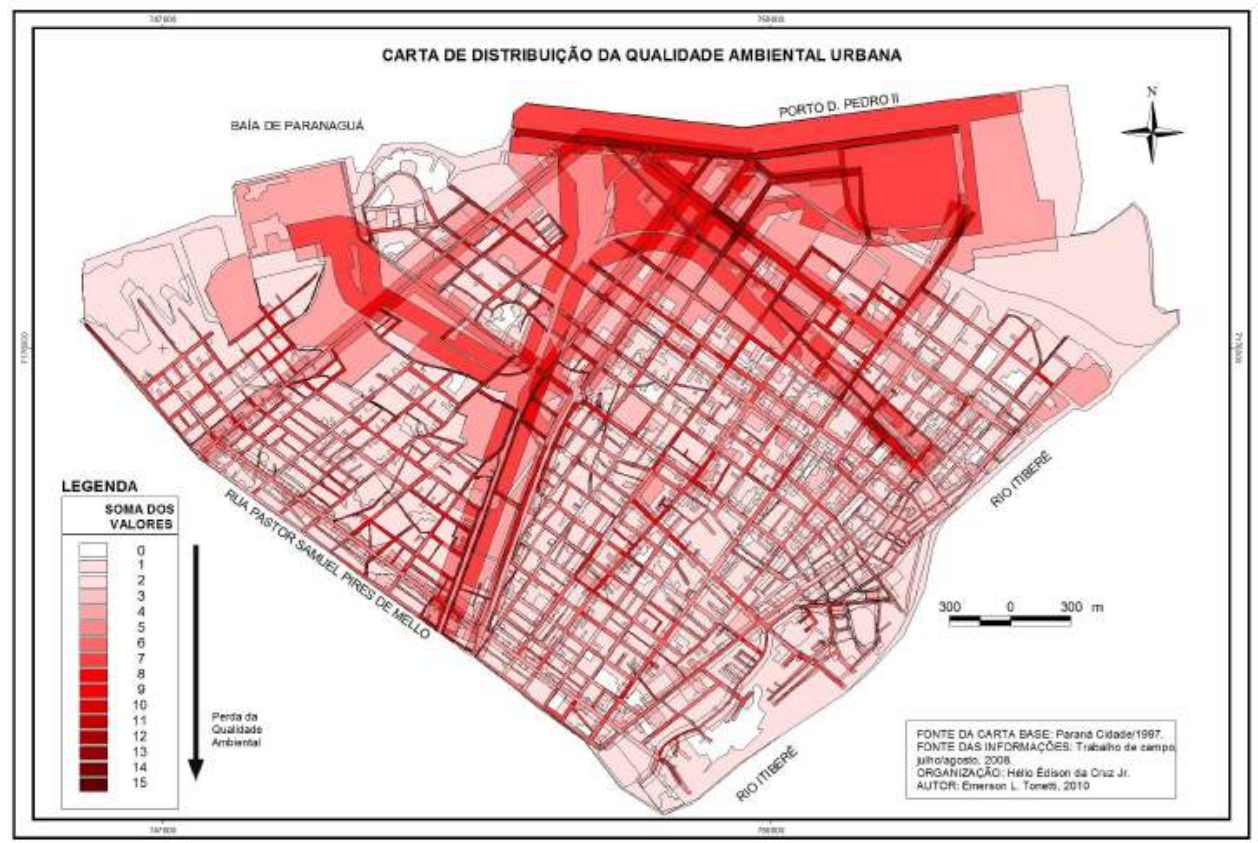

Figura 12: Carta da qualidade ambiental urbana na área de estudo. 
Os locais contínuos com melhor qualidade ambiental encontram-se na periferia da área de estudo, exceto a área do porto, e correspondem aos bairros com predomínio do uso residencial, com vias sem tráfego intenso de veículos e próximos a locais com maiores manchas de cobertura vegetal (FIGURAS 5, 7 e 8).

$\mathrm{Na}$ Carta de Qualidade Ambiental nota-se uma grande área contínua na parte central e norte, com tons mais escuros do vermelho, indicando os locais com menor qualidade ambiental. Compreende toda faixa portuária e as principais vias de acesso ao porto e aos armazéns, além de outras atividades relacionadas ao porto. Nestes locais tem-se a maior concentração dos usos potencialmente causadores de poluição e vias com tráfego intenso de caminhões e trens, considerados com a maior capacidade de causar poluição (FIGURAS 7 e 8).

As vias com tráfego intenso de veículos leves (carros e motos) também se destacam na Carta de Qualidade Ambiental pela grande área atingida nas regiões sudeste e leste do local de estudo. Isto evidencia que estas vias podem possuir condições inadequadas para o deslocamento a pé ou com bicicleta devido ao conflito de usos com o tráfego de veículos motorizados. $\mathrm{Na}$ porção leste da área de estudo, que corresponde ao setor histórico, as vias com tráfego intenso de veículos leves e da intensa presença do uso comercial, também constitui uma uni-dade com perda significativa da qualidade ambiental (FIGURAS 7 e 8).

As descrições acima confirmam fato também observado em Nucci (1996) ao estudar um distrito central no município de São Paulo, que por conter infraestrutura (abastecimento de água, energia elétrica, linha telefônica, gás encanado, etc.), fora considerado, pela Prefeitura do Município de São Paulo, apto para o adensamento populacional por meio da verticalização das edificações em detrimento das condições de qualidade do ambiente. Em Paranaguá não ocorreu de forma diferente. O Plano Diretor do município (PARANAGUÁ, 2007) também aponta a área de estudo como área para adensamento, mesmo sem que as condições ambientais possam fornecer suporte para tanto.

\section{Considerações Finais}

A Carta de Qualidade Ambiental evidenciou uma grande área com baixa qualidade que acompanha o traçado das principais vias de acesso rodoviário e ferroviário ao Porto Dom Pedro II, incluindo a própria área do porto. Da mesma forma, a intensa presença do uso comercial elou a intensidade do tráfego de veículos leves em muitas localidades, favorecem as perdas da qualidade ambiental urbana.

Caso não haja fiscalização e controle do tipo de uso e da intensidade de cada uso podem ocorrer mais perdas da qualidade do ambiente na localidade, haja vista a tendência de ampliação dessas atividades econômicas na atual conjuntura e as propostas de adensamento existentes no Plano Diretor do Município.

Os resultados relacionados com a baixa qualidade ambiental mostraram que a presença de um porto, com intensa movimentação de cargas e que pretende se expandir, 
no meio urbano do município, gera uma enorme riqueza econômica e ao mesmo tempo inúmeros problemas ambientais (direta e indiretamente). Compatibilizar as questões econômicas com as ambientais é uma necessidade e exigirá discussões e acordos entre os três poderes do Município de Paranaguá e do Estado do Paraná. O estreitamento dessas relações é fundamental para melhorar a qualidade do ambiente urbano de Paranaguá.

O método aplicado neste trabalho, utilizando a sobreposição dos critérios negativos e em escalas que valorizam a vida do cidadão, mostrou-se viável em termos de tempo e custos, para a identificação e inferência dos locais com baixa qualidade do ambiente. O método trata-se de uma cartografia restritiva, que aponta apenas “onde não se deve", podendo ser complementado por uma cartografia propositiva, que apresente soluções para os problemas identificados.

Os resultados e a aplicação periódica desse método podem ajudar no monitoramento e na melhoria das condições físicas, químicas e biológicas das localidades urbanas por meio da identificação da qualidade do ambiente e dos elementos responsáveis por essa perda nos locais, favorecendo a utilização de medidas incorporadas ao planejamento e gestão do ambiente urbano. Assim, a ocupação do solo urbano baseada na qualidade do ambiente e nos princípios do Planejamento da Paisagem pode ser o caminho para a maior sustentabilidade das cidades.

Cabe destacar as considerações feitas por Scoffham e Vale (1996, p. 72) e Knight (1996, p. 116-119) ao afirmarem que todo ambiente urbano é um recurso finito, havendo então um limite para acomodar o crescimento, um limite além do qual a área se degrada. Esse limite será alcançado entre o balanço da qualidade e da quantidade. A capacidade variará de lugar para lugar, porque cada cidade tem suas próprias características, cultura e estilo de vida, cada uma necessita de liberdade para desenvolver suas próprias estratégias em concordância com a vontade da população e em consonância com as questões da ética e da legalidade em prol da comunidade. Esse balanço tem que ser atingido entre a necessidade por desenvolvimento e os interesses da conservação, sem o sacrifício da qualidade do ambiente, necessário a todo cidadão.

\section{Referências}

BOLUND, P. e HUNHAMMAR, S. Ecosystem services in urban areas. Ecological Economics, 29 (1999) p. 293-301.

BUCCHERI FILHO, A. T. O planejamento dos espaços de uso público, livres de edificação e com vegetação (EUPLEVS) no município de Curitiba, PR: planejamento sistemático ou planejamento baseado em um modelo oportunista? 226p. Tese (Doutorado) - Setor de Ciências da Terra, Universidade Federal do Paraná, Curitiba. 2010. Disponível em: http://dspace.c3sl.ufpr.br/dspace/bitstream/1884/24093/1/TESE\%20Alexandre\%20Theobald o\%20Buccheri\%20Filho.pdf. Acesso em 20 maio de 2014.

CAVALHEIRO, F. Urbanização e alterações ambientais. In: TEUK, S. M. Análise ambiental: uma visão multidisciplinar. UNESP-Fapesp, São Paulo, 1991, pp. 88-99. 
CAVALHEIRO, F.; NUCCI, J. C.; GUZZO, P.; ROCHA, Y. T. Proposição de terminologia para o verde urbano. Boletim Informativo da Sociedade Brasileira de Arborização Urbana, Rio de Janeiro, v. 7, n. 3, p. 7-7, 1999.

ESTÊVEZ, L. F. Relatórios Ambientais Prévios (RAPs) realizados em Curitiba (Pr): uma análise com base nos princípios do Planejamento da Paisagem. 166f. Tese (Doutorado) Setor de Ciências da Terra, Universidade Federal do Paraná, Curitiba. 2014. Disponível em http://dspace.c3sl.ufpr.br:8080/dspace/handle/1884/35880 Acesso em 19 março 2015.

FARIA, G. G.;TONETTI, E. L.; NUCCI, J. C. Qualidade e distribuição das calçadas e ciclovias na área central de Paranaguá (PR) Brasil: uma contribuição à mobilidade na cidade. In: XV Simpósio Brasileiro de Geografia Física Aplicada, 2013. Anais ... Vitória: UFES, 2013. v. 9. p. 31-39.

HOUGH, M. Naturaleza y ciudad: planificacion urbana y processos ecologicos. Barcelona: G. Gilli, 1998. 315 p.

JACKSON, L.E. The relationship of urban design to human health and condition. Landscape and Urban Planning 64 (2003) 191-200.

KAMP, I. van; LEIDELMEIJER, G. M.; HOLLANDER, A. Urban environmental quality and human well-being: towards a conceptual framework and demarcation of concepts; a literature study. Landscape and Urban Planning, 65, 2003, p. 5 - 18.

KIEMSTEDT, H.; von HAAREN, C.; MÖNNECKE, M.; OTT, S. Landscape Planning: contents and procedures. Hanover: The Federal Ministry for the Environment, Nature Conservation and Nuclear Safety, Universidade de Hanover, 1998, 39p.

KNIGHT, C. Economic and social issues. In: JENKS, M.; BURTON, E. e WILLIAMS, K. The Compact City: A Sustainable Urban Form? London: E \& FN SPON, 1996. 350p. p. 114121.

LÖTSCH, B. In search of human scale. Garten und Landschaft n. 6, 1984, ed. DGGL, Zeitschrift der Deutschen Gesellschaft für Garten kunst und Landschaftspflege.19-26.

MARCUS, M.G.; DETWYLER, T.R. Urbanization and environment. Bermont/Cal., Duxburg Press, 1972.

MOTA, S. Urbanização e meio ambiente. Rio de Janeiro: ABES, 1999.

NUCCI, J. C. Qualidade ambiental e adensamento: um estudo de Planejamento da Paisagem do distrito de Santa Cecília (MSP). Tese de doutorado. Universidade de São Paulo. Programa de Pós-Graduação em Geografia Física. 1996.

NUCCI, J. C. Qualidade Ambiental e Adensamento Urbano: um estudo de ecologia e planejamento da paisagem aplicado ao distrito de Santa Cecilia (MSP). Curitiba: Edição do autor, 2008 ( $2^{\mathrm{a}}$ ed.). 142p. Disponível em

www.geografia.ufpr.br/laboratorios/labs/?pg=publicacoes-php Acesso em 15 dezembro 2008. 
NUCCI, J. C. Ecologia e Planejamento da Paisagem. In: Douglas Gomes dos Santos; João Carlos Nucci. (Orgs.). Paisagens Geográficas. Um tributo a Felisberto Cavalheiro. Campo Mourão: Editora da FECILCAM, 2009, p. 50-64. Disponível em $\mathrm{http}: / /$ www.fecilcam.br/editora/index.php?option=com_content\&task=blogcategory\&id=6\&I temid=12 Acesso em 28 abril 2010.

NUCCI, J. C. Aspectos teóricos do Planejamento da Paisagem. In: João Carlos Nucci (Org.) Planejamento da Paisagem como subsídio para a participação popular no desenvolvimento urbano. Estudo aplicado ao bairro de Santa Felicidade - Curitiba/PR. Curitiba:

LABS/DGEOG/UFPR, 2010, p. 14-25. Disponível em www.geografia.ufpr.br/laboratorios/labs/?pg=publicacoes-php Acesso em 20 agosto 2008.

PARANAGUÁ. Lei Orgânica do Município de Paranaguá, 1990. Disponível em http://www.helts.com.br/paranagua/plano_diretor.php. Consultado em 10 de dezembro de 2008.

PARANAGUÁ. Lei Complementar $n^{\circ} 068$, de 23 de agosto de 2007. Institui o Plano Diretor de Desenvolvimento Integrado no Município de Paranaguá. Disponível em http://www.helts.com.br/paranagua/plano_diretor.php . Acesso em 10 de dezembro de 2008.

SCOFFHAM, E. e VALE, B. How compact is sustentainable - How sustainable is compact? In: JENKS, M.; BURTON, E. e WILLIAMS, K. The Compact City: A Sustainable Urban Form? London: E \& FN SPON, 1996. 350p. p. 66-73.

SILVA, K. S.; LOPES, A. S. Excesso de peso, pressão arterial e atividade física no deslocamento à escola. Arq. Bras. Cardiol. vol.91, no.2, São Paulo, Aug., 2008. Disponível em http://www.scielo.br/scielo.php . Acesso em 15 junho 2009.

SOUZA, F. X. S. (Coord.) Projeto para mapear os sistemas de drenagem urbana de Paranaguá. Instituto Superior do Litoral do Paraná (ISULPAR), Paranaguá, 2009.

SPIRN, A. W. O Jardim de Granito: a natureza no desenho da cidade. São Paulo, Editora da Universidade de São Paulo, 1995.

SUKOPP, H.; WERNER, P. Naturaleza en las ciudades. Madrid: Ministério de Obras Públicas y Transportes (MOPT), 1991.

TONETTI, E. L. Potencialidades de adensamento populacional por verticalização das edificações e qualidade ambiental urbana no município de Paranaguá, Paraná, Brasil. 235f. Tese (Doutorado) - Setor de Ciências da Terra, Universidade Federal do Paraná, Curitiba. 2011. Disponível em http://200.17.203.155/index.php?codigo_sophia=285569 Acesso em 12 abril 2011.

TONETTI, E. L.; NUCCI, J. C. Arborização viária na área central de Paranaguá (PR) Brasil. Revista Geografar (UFPR), v. 7, p. 53-67, 2012.

TONETTI, E. L.; NUCCI, J. C.; CRUZ JUNIOR, H. E. . Cobertura vegetal na área urbana de Paranaguá-PR. In: XIV Simpósio Brasileiro de Geografia Física Aplicada, 2011, Dourados, 
MS. Dinâmicas Socioambientais, das inter-relações às interdependências. Anais... Dourados: UFGD, 2011. v. 1. p. 1-12.

TONETTI, E. L.; NUCCI, J. C.; SOUZA, F.X.S. ; VALASKI, S. Alagamentos frequentes na área urbana de Paranaguá-PR. Geografia (Londrina), v. 22, p. 43-56, 2013.

TONETTI, E. L.; NUCCI, J. C.; VALASKI, S. Espaços livres na área urbana de Paranaguá (Paraná, Brasil). Revista da Sociedade Brasileira de Arborização Urbana, v. 7, p. 37-50, 2012.

ZEKCER, D. Esporte, transporte e saúde: é possível viver sem carro? Debate de 20. setembro 2008. Disponível em http://www.jornaldedebates.com.br Acesso em 25 junho 2009.

Agradecimentos ao CNPq pela concessão de bolsa de produtividade em pesquisa ao segundo autor e a CAPES pela concessão de bolsa de mestrado ao terceiro autor.

\author{
Emerson Luis Tonetti \\ Biólogo, Mestre em Ciências Biológicas e Doutor em Geografia pela Universidade \\ Federal do Paraná. Professor do Instituto Federal do Paraná- campus Paranaguá. \\ Conjunto Residencial Moradias Porto Seguro. Rua Antônio Carlos Rodrigues, 453, \\ Paranaguá/PR. CEP 83215-750. \\ emerson.tonetti@ifpr.edu.br
}

\title{
João Carlos Nucci
}

Biólogo e Doutor em Geografia Física pela Universidade de São Paulo.

Professor do Departamento de Geografia da Universidade Federal do Paraná.

Setor de Ciências da Terra, Depto. de Geografia. Centro Politécnico, Jardim das Américas C.P. 19001 CEP.: 81531 - 980 Curitiba/PR.

jcnucci@gmail.com

\section{Felipe Vanhoni Jorge}

Geógrafo e Doutorando do Programa de Pós-graduação em Geografia do Departamento de Geografia da Universidade Federal do Paraná.

Setor de Ciências da Terra, Depto. de Geografia. Centro Politécnico, Jardim das Américas C.P. 19001 CEP.: 81531 - 980 Curitiba/PR.

felipevanhoni@hotmail.com 